\title{
Extraction of Collagen from the Skin of Kacang Goat and Production of Its Hydrolysate as an Inhibitor of Angiotensin Converting Enzyme
}

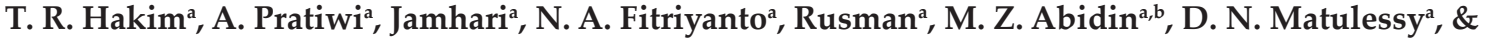 \\ Y. Erwanto ${ }^{*, a, c}$ \\ aDepartment of Animal Products Technology, Faculty of Animal Science, Universitas Gadjah Mada, \\ Jalan Fauna No. 3, Bulaksumur, Yogyakarta 55281, Indonesia \\ bDepartment of Chemical and Pharmaceutical Biology Groningen Research Institute of Pharmacy, \\ University of Groningen, \\ Antonius Deusinglaan 1, Groningen, 9713 AV, Netherlands \\ Institute for Halal Industry \& System, Universitas Gadjah Mada, \\ Bulaksumur, Yogyakarta 55281, Indonesia \\ *Correspondence author: yunyer@ugm.ac.id \\ (Received 13-08-2020; Revised 09-12-2020; Accepted 17-12-2020)
}

\begin{abstract}
The study was designed to determine the potential of collagen hydrolysate produced from the skin of Kacang goat through chymotrypsin hydrolysis to be used as an inhibitor of angiotensin converting enzyme (ACE). This research was conducted in three replications, with the measured parameters include ACE inhibitory potential and collagen hydrolysate fractionation. The results showed that collagen extraction of Kacang goat skin by chymotrypsin hydrolysis yielded $9.74 \%$ (dry matter, v/v) collagen, with $\mathrm{pH}$ at 6.6. The extracted collagen contained $\alpha 1$, $\alpha 2$, and $\beta$ collagen chains with molecular weights of $151 \mathrm{kDa}, 141 \mathrm{kDa}$, and $240 \mathrm{kDa}$, respectively. Furthermore, the collagen hydrolysis produced protein peptides confirmed at molecular weights of 43 to 107 kDa. The hydrolysate fractionation at molecular weights of $<3 \mathrm{kDa}, 3-5 \mathrm{kDa}$, and $>5 \mathrm{kDa}$ showed proteins concentrations of $2.33 \mathrm{mg} / \mathrm{mL}, 3.81 \mathrm{mg} / \mathrm{mL}$, and $3.93 \mathrm{mg} / \mathrm{mL}$, respectively. The hydrolysate fractionation with molecular weight $<3 \mathrm{kDa}$ showed to have ACE inhibition activity with the $\mathrm{IC}_{50}$ value of $0.47 \mathrm{mg} / \mathrm{mL}$. The study concluded that collagen hydrolysate extracted from the skin of Kacang goat had a promising potential as a source of antihypertensive agent.
\end{abstract}

Keywords: antihypertensive; chymotrypsin; collagen of goat skin; hydrolysate; $\mathrm{IC}_{50}$

\section{INTRODUCTION}

The research on goats in Indonesia has been focused on improving meat and milk production. The study to explore and evaluate the potential use of animal skin for the production of beneficial derivative compounds such as gelatin, collagen, or bioactive peptide is limited. Goat skin is one of the by-products from slaughterhouses that can be consumed with high protein content. The physical structure of goat skin is composed of connective tissue, which is a micro component of fibrils and fibroblasts that form collagen and elastin tissue. Moreover, raw goat skin contained 60\%$70 \%$ water, $25 \%-32 \%$ protein, $2.2 \%-3.2 \%$ fiber protein, and $7 \%-7.3 \%$ crude fat (Ajayi \& Akomolafe, 2016) (Naffa et al., 2019). However, the collagen protein of goat skin has low digestibility due to the strong protein-binding bonds in the form of the triple helix. The collagen cleavage into smaller compounds can be done through enzymatic hydrolysis. The exploration of alternative protein sources in regards to their functional properties has been growing continuously and getting more attention as the trend to use natural food as an additive (Sadeghi et al., 2019).

Enzymatic hydrolysis is preferred over chemical hydrolysis since the process can be controlled, and the final product can be further developed (Iltchenco et al., 2017). The enzymes used for hydrolysis include pepsin, trypsin, and chymotrypsin (Sujarwanto et al., 2018; Winarti et al., 2019). The hydrolysis using various digestive enzymes have shown to be able to produce bioactive peptide compounds as antihypertensive agents from the animal products such as meat of buffalo (Sujarwanto et al., 2018), foot of chicken (Bravo et al., 2019), milk of goat (Widodo et al., 2019), the meat of rabbit (Permadi et al., 2019), and meat of duck (Winarti et al., 2019). The bioactive peptide is able to inhibit the activity of angiotensin converting enzyme in the RAAS system (Renin-Angiotensin-Aldosterone System), which causes hypertension due to the constriction of blood vessels (Hsueh and Wyne, 2011). The ability of enzymes to hydrolyze proteins varies greatly, depends on the specific nature of the enzyme. The chymotrypsin enzyme tends to cut the peptide bonds formed by 
large molecular and hydrophobic amino acid residues. Chymotrypsin cleaves peptide bonds at leucine-leucine position, and previous research resulted from the leu-thr-glu-ala-pro-leu-asn-prolys-ala-arg-asn-glu-lys sequence with potential as an ACE inhibitor (Jamhari et al., 2013). Therefore, the use of the chymotrypsin enzyme to hydrolyze the collagen contained in the skin of the goat for the production of oligo-peptide and their potential as an ACE inhibitor has never been studied. This study aims to determine the potential production of collagen-protein hydrolysate extracted from the skin of local Kacang goat using the chymotrypsin enzyme. The collagen hydrolysate can be used as an inhibitor of angiotensin converting enzyme (ACE).

\section{MATERIALS AND METHODS}

\section{Materials}

The skin was obtained from 1.5 years of male Kacang goat from Gunung Kidul Regency, Yogyakarta, Indonesia. Pepsin (porcine stomach mucosa) and chymotrypsin were purchased from the Sigma-Aldrich Chemical Industry Ltd., Germany. Angiotensinconverting enzyme (ACE) from rabbit lung was obtained from the Sigma Chemical Co., St. Louis, USA, and hippuryl-L-histidyl-leucine (HHL) free base was purchased from Nacalai Tesque, Kyoto, Japan. No animals experimented in the present study. Thus, there was no requirement for ethical approval.

\section{Skin Preparation}

Goat skin was prepared from the remaining meat, fat, and dirt. The hairs in the skin were removed by scraped using a knife, then rinsed with running water and drained for 30 minutes until the water does not drip. The skin was cut into small pieces and weighed as much as 100 grams. Before extraction, goat skin was tested for proximate assay (AOAC, 1990).

\section{The Production of Collagen from the Skin of Kacang Goat}

Collagen was extracted by the enzymatic method according to Wahyuningsih et al. (2018). Small pieces of goat skin, each with a weight of 100 grams, were immersed in $0.1 \mathrm{M} \mathrm{NaOH}$ solution at a ratio of 1:10 $(\mathrm{w} / \mathrm{v})$ for 10 minutes then the solution was discarded. Extraction was done by immersing the skin in a solution of $0.5 \mathrm{M}$ acetic acid containing $0.1 \%(\mathrm{w} / \mathrm{v})$ pepsin at a ratio of $1: 10(\mathrm{w} / \mathrm{v})$ for 24 hours at $4^{\circ} \mathrm{C}$. The mixture was filtered using Whatman filter paper No. 1. Subsequently, the hydrolysate was precipitated with $2.6 \mathrm{M} \mathrm{NaCl}$ overnight at $4^{\circ} \mathrm{C}$. The extract was centrifuged at a speed of $4500 \mathrm{~g}$ for 30 minutes at $4^{\circ} \mathrm{C}$. The pellet was dissolved with $0.5 \mathrm{M}$ acetic acid (1:5 ratio) and dialyzed with 0.1 M phosphate buffer for 24 hours with periodic solution replacement and finally washed with distilled water for 2 hours. The extracted collagen was freeze-drying. The yield of collagen was obtained by the formula below:
Collagen yields $(\%)=($ Dry weight of collagen $/$ Initial weight) $\times 100 \%$

\section{Characterization of Collagen Extracted from the Skin of Kacang Goat}

The extracted collagen was characterized for $\mathrm{pH}$ and molecular weight characteristics, following the methodology of Alfaro et al. (2013) and Vidal et al. (2019b). The $\mathrm{pH}$ of collagen was measured by weighing one gram of sample then dissolved into $100 \mathrm{~mL}$ of distilled water. The $\mathrm{pH}$ of the collagen solution was measured using the $\mathrm{pH}$ meter $(\mathrm{pH}$ meter, Hanna Instrument). The molecular weight of collagen was determined using SDS-PAGE. The electrophoresis gel used in this procedure contains 15\% resolving gel and $4 \%$ stacking gel. A collagen sample at the weight of 0.01 gram was dissolved in $20 \mathrm{mM} \mathrm{NaOH}$ with $0.1 \mathrm{M}$ buffer phosphate $(\mathrm{pH} 8.3)$ in a ratio of 1:5. Collagen was then homogenized using a vortex mixer (Velp ZX4, Velp Scientifica, Italy). A total of $10 \mu \mathrm{L}$ of collagen solution was mixed with $4 \mu \mathrm{L}$ of loading SDS buffer, then heated with a water bath at $85^{\circ} \mathrm{C}$ for five minutes. The collagen solution was cooled and centrifuged at $3000 \mathrm{rpm}$ for 30 seconds. Collagen samples were loaded into the electrophoresis gel with a voltage of $110 \mathrm{~V}$ for 150 minutes. The gel was stained using $0.25 \%$ Coomassie blue, soaked for 6 hours, then de-stained for 15 minutes. The gel was fixed in a $10 \%$ solution of acetic acid, observed, and measured the band formed.

\section{Hydrolysate Production Derivate from the Collagen of Goat Skin}

The collagen was hydrolyzed and fractionated to obtain potential bioactive peptide hydrolysate according to Jamhari et al. (2013) with a slight modification. Collagen was hydrolyzed with the chymotrypsin enzyme. Collagen was dissolved in a phosphate buffer mixture ( $\mathrm{pH} 8.3$ ) with $20 \mathrm{mM} \mathrm{NaOH}$. The chymotrypsin enzyme at a concentration of $2 \mathrm{U} / \mathrm{mg} / \mathrm{mL}$ was added to the collagen solution, then incubated at $37^{\circ} \mathrm{C}$ for 1 hour. The hydrolysis reaction was stopped by heating at $95^{\circ} \mathrm{C}$ for 10 minutes, then cooled on ice before fractionation. The fractionation of collagen hydrolysate was conducted through two stages of filtering. In the first stage, the hydrolysate was fractionated using a $5 \mathrm{kDa}$ Vivaspin concentrator. Two milliliters of hydrolysate was put in a column/filtrate tube, then put in a centrifuge. Centrifugation was carried out at a speed of $4500 \mathrm{~g}\left(4^{\circ} \mathrm{C}\right.$ temperature) for 45 minutes. The filtrate of $5 \mathrm{kDa}$ was collected for smaller fractions. The filtrate from the filtration results was taken for the second stage of fractionation using a $3 \mathrm{kDa}$ centrifugal filter. Centrifugation was carried out at a speed of $4500 \mathrm{~g}$ ( $4^{\circ} \mathrm{C}$ temperature) for 45 minutes. The filtrate of $3 \mathrm{kDa}$ was collected as a result of $<3 \mathrm{kDa}$ filtration. Homogenate was collected as a result of 3-5 $\mathrm{kDa}$ dissolved protein. The levels of dissolved protein were tested to determine the concentration of potential bioactive peptides in each fraction. 
Hydrolysate of collagen was measured using the waddle method (Wolf, 1983). The samples of fractionated protein were taken at a volume of $5 \mu \mathrm{L}$ then put in $1 \mathrm{~mL}$ of $20 \mathrm{mM} \mathrm{NaOH}$ solution and buffer phosphate ( $\mathrm{pH}$ 8.3) (ratio of 1: 5). The absorbance of the sample was measured at $215 \mathrm{~nm}$ and $225 \mathrm{~nm}$ wavelengths using a spectrophotometer. The hydrolysate of collagen was calculated by the formula:

Dissolved protein $(\mathrm{mg} / \mathrm{mL})=(\mathrm{A} 215-\mathrm{A} 225) \times 28.8$

where A215 was absorbance at $\lambda 215$ and A225 was absorbance at $\lambda 225$.

\section{Determination of ACE Inhibiting Potential}

The determination of ACE inhibiting potential was measured following Liu et al. (2013). Hydrolysate of collagen solution $(207 \mu \mathrm{L})$ containing ACE inhibitor peptides with protein concentrations of $0.6,0.8,1.0$, $1.2,1.4$, and $1.6 \mathrm{mg} / \mathrm{mL}$ was mixed with $25 \mu \mathrm{L}$ of 5.0 $\mathrm{mM}$ HHL substrate dissolved in $100 \mathrm{mM}$ borate buffer $(\mathrm{pH} \mathrm{8,3)}$ and $300 \mathrm{mM} \mathrm{NaCl}$, and then the samples were pre-incubated for 5 minutes in a water bath at $37^{\circ} \mathrm{C}$. The reaction started with the addition of $18 \mu \mathrm{l} 0.018 \mathrm{U}$ ACE dissolved in borate buffer ( $\mathrm{pH} 8.3$ ). Incubation was carried out in a water bath for 30 minutes at $37^{\circ} \mathrm{C}$. The reaction was stopped by the addition of $250 \mu \mathrm{L} 0.1 \mathrm{~N} \mathrm{HCl}$, except for blanks that were added $250 \mu \mathrm{L} 0.1 \mathrm{~N} \mathrm{HCl}$ before incubation. The product of the reaction (hippuric acid) was extracted with the addition of $1.5 \mathrm{ml}$ of ethyl acetate and shaken for 3 minutes. The mixture was then centrifuged at a speed of 3,600 rpm for 15 minutes. One milliliter of the supernatant was taken and transferred to another test tube, then dried at $100^{\circ} \mathrm{C}$ for 60 minutes. The test tube was then cooled to room temperature for 30 minutes. The hippuric acid released by ACE was determined spectrophotometrically, with a wavelength of $228 \mathrm{~nm}$. The percentage of ACE inhibitory activity was calculated using the formula:

Inhibitory activity $(\%)=[($ Ec-Es) $/($ Ec-Eb) $) \times 100 \%$

where Ec was absorbance of the control, Es was absorbance of sample, Eb was absorbance of blank.

The concentration of ACE inhibitors to inhibit 50\% of the ACE activity is called the $\mathrm{IC}$ value $\left(\mathrm{IC}_{50}\right) . \mathrm{IC}_{50}$ was obtained by making a regression equation of the inhibitory activity of several serial dilution samples. All measurements were carried out for triplicate. The regression curve of the $\mathrm{IC}_{50}$ calculation was described as a sigmoid curve by plotting ACE activity (\%) versus the inhibitor concentration and performing a model fit using Bayesian data analysis (von der Linden et al., 2014).

\section{Experimental Designs and Data Analysis}

This experiment was designed as an exploratory study using homogenized collagen of goat skin. The obtained data on the characters of collagen in the skin of Kacang goat was shown as descriptive analysis. The molecular weight of collagen was visualized as SDSPAGE pattern and calculated by regression analysis. The analysis of variance with one way pattern using SPSS was applied to determine the differences among the protein content after various sizes of ultrafiltration application. The ACE inhibition data were collected and calculated statistically for the $\mathrm{IC}_{50}$ through the sigmoid regression analysis.

\section{RESULTS}

\section{The Characterization of Collagen Produced from the Skin of Kacang Goat}

The chemical composition of the skin of Kacang goat and the yields of collagen produced are presented in Table 1 and Table 2. Table 1 shows the chemical composition of the skin of Kacang goat, which protein content more than $30 \%$. It means that goat skin is a good source of collagen protein and has the potential as a source of many derivative-protein products, including bioactive peptides. The yield of collagen extraction derived from the skin of Kacang goat using pepsin in 24

Table 1. Chemical composition of skin of Kacang goat

\begin{tabular}{lc}
\hline Compositions & Percentage (\%) \\
\hline Water content & 70.19 \\
Ash content & 0.36 \\
Fat content & 0.49 \\
Protein content & 31.05 \\
\hline
\end{tabular}

Table 2. The comparison of collagen characteristics hydrolyzed from the skins of Kacang goat to the other animal's skin

\begin{tabular}{|c|c|c|c|c|c|}
\hline Substrate & Enzyme & $\begin{array}{l}\text { Incubation } \\
\text { time }\end{array}$ & $\begin{array}{l}\text { Collagen yield (dry } \\
\text { weight, \%) }\end{array}$ & $\mathrm{pH}$ & Reference \\
\hline Skin of Kacang goat & Pepsin & 24 hours & $13.56 \pm 0.02$ & 6.6 & In this Study \\
\hline Lamb slaughter by-product & Pepsin & 72 hours & 12.3 & - & Vidal et al., 2020 \\
\hline Sheep slaughter by-product & & & 8.88 & & \\
\hline Skin of rabbit & Pepsin & 48 hours & 71 & 6.3 & Martínez-Ortiz et al., 2015 \\
\hline Bull hide & Pepsin & 24 hours & $30.20 \pm 0.87$ & - & (Noorzai et al., 2020). \\
\hline Calf hide, & & & $19.50 \pm 0.78$ & & \\
\hline Cow hide, & & & $26.90 \pm 0.32$ & & \\
\hline Bovine face-pieces & & & $15.40 \pm 1.16$ & & \\
\hline Ox hide & & & $30.10 \pm 0.26$ & & \\
\hline
\end{tabular}


hours of incubation time was obtained at $9.73 \mathrm{~g}$ per 100 g sample or $9.73 \%$ (Table 2 ).

Figure 1 shows the two main collagen chains, i.e., $\alpha$ and $\beta$ band forms. The molecular weights of $\alpha 1, \alpha 2$, and $\beta$ chains of collagen from the skin of Kacang goat were $151 \mathrm{kDa}, 141 \mathrm{kDa}$, and $240 \mathrm{kDa}$, respectively.

\section{Collagen Hydrolysate of Goat Skin Produced by Chymotrypsin Hydrolysis}

Figure 2 shows the results of SDS-PAGE testing of collagen obtained from the skin of Kacang goat hydrolyzed using the chymotrypsin enzyme. The results of the molecular weight pattern of collagen hydrolysate in various hydrolysis times of 15, 30, 45, and 60 minutes were relatively showed the same molecular weight. The molecular weights of collagen hydrolysate after hydrolysis with chymotrypsin were observed between 43 to $107 \mathrm{kDa}$. The $\alpha 1, \alpha 2, \beta$ chains, and the hydrolyzed band (hydrolysis for 15 to 60 minutes) look fading.

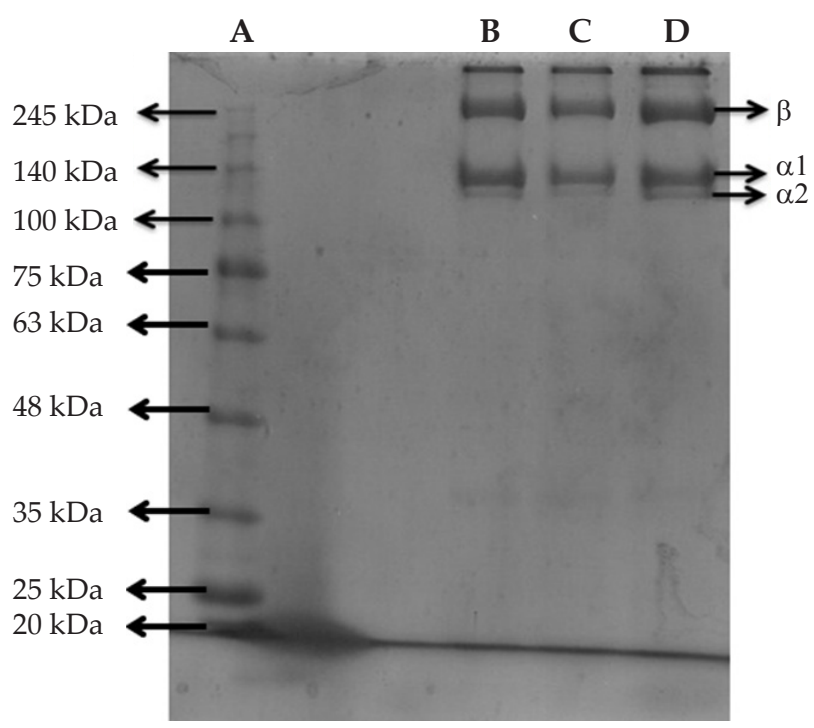

Figure 1. SDS-PAGE patterns of collagen extracted from the skin of Kacang goat; (A) Marker 20 to 245 kDa; (B-D) Collagens isolate batch 1 to 3 .

Table 3. Angiotensin-converting enzyme (ACE) inhibitory activity (\%) of fractionate protein of collagen hydrolysate with molecular weight $<3 \mathrm{kDa}$

\begin{tabular}{ccc}
\hline $\begin{array}{c}\text { Protein level } \\
(\mathrm{mg} / \mathrm{mL})\end{array}$ & $\begin{array}{c}\text { Protein in assay } \\
(\mathrm{mg} / \mathrm{mL})\end{array}$ & $\begin{array}{c}\text { Inhibitory percentage } \\
(\%)\end{array}$ \\
\hline 1.8 & 22.06 & $93.07 \pm 0.74$ \\
1.6 & 19.61 & $88.27 \pm 0.71$ \\
1.4 & 17.16 & $80.97 \pm 2.75$ \\
1.2 & 14.71 & $76.20 \pm 3.10$ \\
1 & 12.25 & $69.74 \pm 2.79$ \\
0.8 & 9.8 & $66.02 \pm 2.23$ \\
0.6 & 7.35 & $58.87 \pm 3.00$ \\
\hline
\end{tabular}

\section{The Potential of Protein Hydrolysate as an ACE Inhibitor Agent}

Fractionation is one of the methods of isolating peptides of a certain size by filtration (Liu et al., 2013). The results of fractionation of collagen hydrolysate were determined for dissolved protein levels, and their activity tests as ACE inhibitors are presented in Table 3. Ultrafiltration separated the protein fragments based on their molecular weights, and the data showed no significant differences ( $>00.05)$ among the filtrates with various filter sizes on the protein concentration (Table 4).

The measurement of ACE was performed to observe the potential of collagen hydrolysate proteins as ACE inhibitors. The $\mathrm{IC}_{50}$ was calculated by regression equations between hydrolysate protein content and the inhibition percentage, as presented in Figure 4. The data showed that hydrolysate protein produced by treating the collagen with chymotrypsin followed by ultrafiltration resulted from $\mathrm{IC}_{50}$ was $0.47 \mathrm{mg} / \mathrm{mL}$.

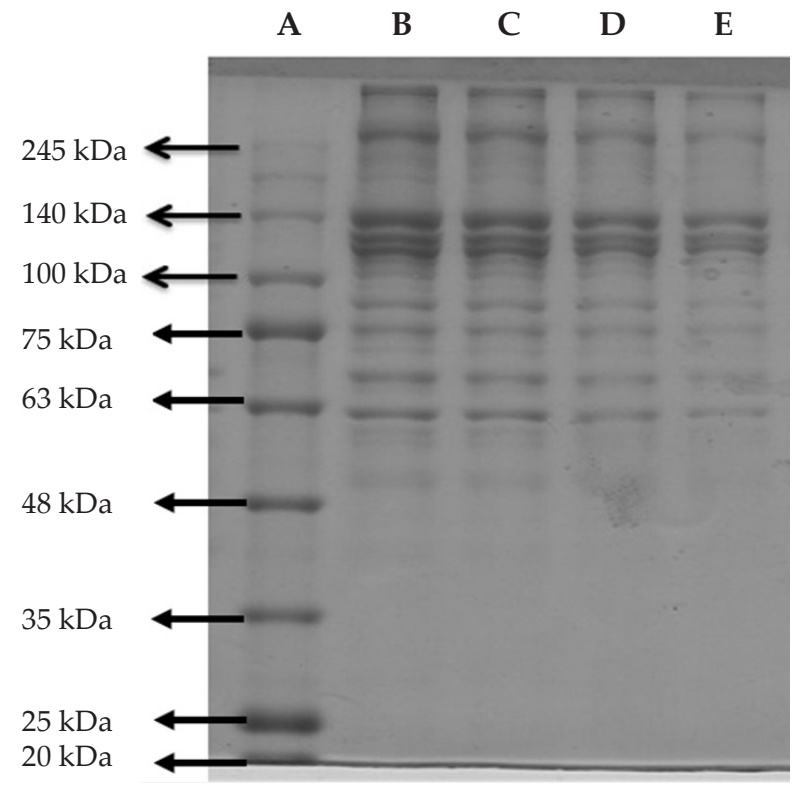

Figure 2. SDS-PAGE patterns of collagen in the skin of Kacang goat hydrolyzed with chymotrypsin at different incubation times; (A) Marker 20 to $245 \mathrm{kDa}$; (B) 15 minutes; (C) 30 minutes; (D) 45 minutes, and (E) 60 minutes.

Table 4. Protein concentration of fractionation samples with various filtrate sizes

\begin{tabular}{cc}
\hline $\begin{array}{c}\text { Molecular weight of filtrate } \\
(\mathrm{kDa})\end{array}$ & $\begin{array}{c}\text { Protein content } \\
(\mathrm{mg} / \mathrm{mL})^{\mathrm{ns}}\end{array}$ \\
\hline$<3$ & $2.04 \pm 0.52$ \\
$3-5$ & $2.97 \pm 0.65$ \\
$>5$ & $3.69 \pm 1.12$ \\
\hline
\end{tabular}

Note: $n s=$ Non significant 


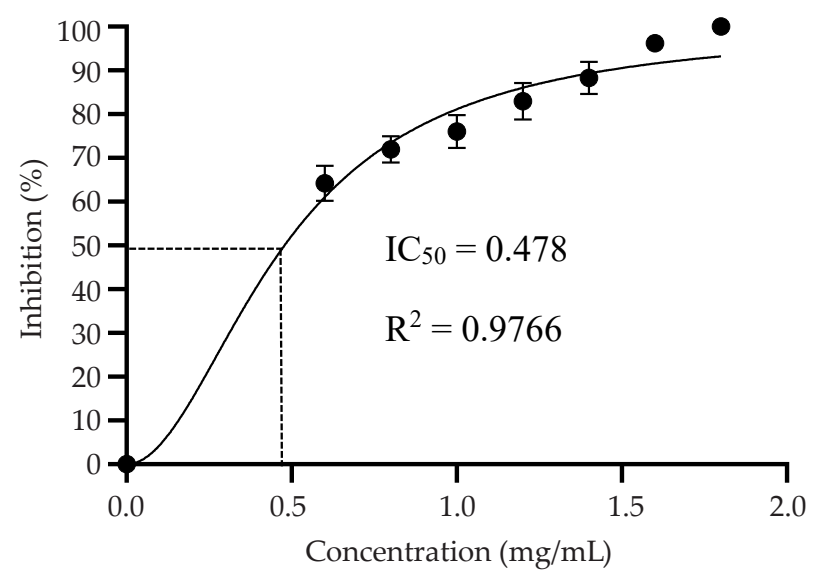

Figure 3. Sigmoid curve between angiotensin-converting enzyme (ACE) inhibition and protein concentration of collagen hydrolysates; (C) 30 minutes; (D) 45 minutes, and (E) 60 minutes.

\section{DISCUSSION}

The protein analysis of the skin of Kacang goat was obtained at $30.54 \%$, which is lower than that of Ettawa goat (46.89\%) (Kasim et al., 2013) and dog (32.17\%), but higher than that of the Nigerian goat $(27.36 \%)$ and leather of pigs (25.36\%) (Ajayi \& Akomolafe, 2016). Generally, the collagen content of hiding is around 30\% of the total body protein (Chuck-Hernández \& Ozuna, 2019). It has the potential for collagen with a high denaturation temperature compared to the skins of other animals. The presence of protein in the skins of livestock can also indicate the potential of the skin to produce collagen structure and product yield. Collagen molecules are triple-helix of three different alpha chains of repeating amino acid units (Gly-X-Y) N, where $X$ and $Y$ are any amino acids. However, $\mathrm{X}$ is often a proline, and $\mathrm{Y}$ is often hydroxyproline (Noorzai et al., 2020).

The yield of isolated collagen is affected by several factors, such as the condition of raw material, extraction method, incubation time, and temperature. The condition of raw materials allows the condition of different tissue-protein compatibilities so that it affects the enzyme activity and the length of time required to hydrolyze the substrate by the enzyme. Incubation time has a higher influence on the yield of collagen. The longer incubation time will produce the maximal hydrolysis process that eventually will produce higher yields (Noorzai et al., 2020). The skin of sheep has a collagen yield of $8.88 \%$ (Vidal et al., 2019b) and the skin of the rabbit calf has a collagen yield of $19.5 \%$ (Martinez-ortiz et al., 2015). The rapid hydrolysis rate of collagen tends to increase the number of collagen molecules produced that will be converted and will eventually increase the yield value (Muyonga et al., 2003). The protein content of collagens is affected by the extraction method since the more drastic extraction processes can result in lower protein contents, as they severely affect the protein structure, breaking it into smaller fractions (Vidal et al., 2019a).
The $\mathrm{pH}$ of isolated collagen in this study was 6.6. Previous research by Tabarestani et al. (2012) showed that collagen solubility was affected by $\mathrm{pH}$ values. The $\mathrm{pH}$ value of 6.6 is in accordance with the standards of BSN (2014) that the standard $\mathrm{pH}$ values range from 6.5 to 8 . The yields of collagen extracted from the skin of Kacang goat were tested for molecular weight by SDSPAGE. The bands formed from SDS-PAGE extract of collagen from the skin of Kacang goat are presented in Figure 1.

The SDS-PAGE of collagen were observed from previous works with different species in the skin of rabbit showing $\alpha 1, \alpha 2$, and $\beta$ chain conformations (Martínez-Ortiz et al., 2015). Collagen containing these two chains can be grouped into type I collagen (Khiari et al., 2014; Luderman et al., 2017), which is a characteristic of collagen originating from the skin. The $\beta$ chain (dimer) observed in the electrophoresis results show that collagen has intramolecular and intermolecular crosslink components (Lodhi et al., 2018).

One of the characteristics of hydrolyzed proteins is the decreasing of molecular weight (León-López et al., 2019) due to the hydrolysis of the proteins into smaller peptides with smaller molecular weights (Jamhari et al., 2013). The protein concentrations of collagen hydrolysate are $2.33 \pm 0.38 \mathrm{mg} / \mathrm{mL}$ with the lowest molecular weight fractionation of $<3 \mathrm{kDa}$ ) (Table 3) with ACE inhibiting potential can be seen in Figure 3. Based on the measurement of $\mathrm{IC}_{50}$ of angiotensin converting enzyme described in Figure 3, the inhibition of ACE activity by collagen hydrolysate of the skin of Kacang goat as was measured with $\mathrm{IC}_{50}$ value of $0.47 \mathrm{mg} / \mathrm{mL}$. Previous research in the meat hydrolysate of Kacang goat showed the $\mathrm{IC}_{50}$ value of $0.31 \mathrm{mg} / \mathrm{mL}$ (Jamhari et al., 2013). In addition, $\mathrm{IC}_{50}$ of a milk-protein hydrolysate of the goat was $0.005-0.056 \mathrm{mg} / \mathrm{mL}$ (Espejo-Carpio et al., 2013). $\mathrm{IC}_{50}$ of protein from the leg of native chicken was reported in the level of $0.33 \pm 0.02 \mathrm{mg} / \mathrm{mL}$ (Yuliatmo et al., 2017).

\section{CONCLUSION}

Hydrolysis of collagen from the skin of Kacang goat by using chymotrypsin was more susceptible to the decrease in molecular weight with the increase in the duration of incubation as shown by the SDS-PAGE bands of the $\alpha 1, \alpha 2$, and $\beta$ collagen chains. The ultrafiltration could separate the different sizes of oligopeptide and oligopeptide with the lowest molecular weight showed the highest ACE inhibition activity. The potential candidate to be developed for antihypertensive treatment is the small-fraction peptide having a molecular weight less than $3 \mathrm{kDa}$ with the best ACE inhibition with the $\mathrm{IC}_{50}$ value of $0.47 \mathrm{mg} / \mathrm{mL}$.

\section{CONFLICT OF INTEREST}

We declare that there is no conflict of interest regarding any financial, personal, or organizations related to the material discussed in the manuscript. 


\section{ACKNOWLEDGEMENT}

This research was financially supported by the Indonesian government under the Directorate of Research, Universitas Gadjah Mada, with contract number 1981/UN1/DITLIT/DIT-LIT/PT/2020 and RTA with Contract number 2488/UN1.T.III/DIT-LIT/PT/2020. The author gratefully thanks to Mr. Aldyon for the valuable English editing and suggestion.

\section{REFERENCES}

Ajayi, E. O. B. \& S. F. Akomolafe. 2016. A comparative study on nutritional composition, mineral content and amino acid profile of the skin of four different animals. Food Sci. Nutr. 2:1-7. https://doi.org/10.24966/FSN-1076/100012

Alfaro, A. D. T., G. G. Fonseca, E. Balbinot, A. Machado, \& C. Prentice. 2013. Physical and chemical properties of Wami tilapia skin gelatin. Food Sci. Technol. 33:592-595. https:// doi.org/10.1590/S0101-20612013005000069

AOAC. 1990. Official Methods of Analysis. The Association of Official Analytical Chemists. $15^{\text {th }}$ ed. William Horwith (Ed) Benjamin Franklin Station, Washington DC.

Bravo, F. I., A. M. Capdevila, M. Margalef, A. A. Arnal, \& B. Muguerza. 2019. Novel antihypertensive peptides derived from chicken foot proteins. Mol. Nutr. Food Res. 63:1-8. https:/doi.org/10.1002/mnfr.201801176.

Badan Standarisasi Nasional. 2014. Kolagen Kasar dari Sisik Ikan- Syarat Mutu dan Pengolahan- SNI 8076-2014. Badan Standarisasi Nasional, Jakarta.

Chuck-Hernández, C. \& C. Ozuna. 2019. Chapter 5-Protein Isolates from Meat Processing by-Products. In: Charis M. Galanakis (Ed.). Proteins: Sustainable Source, Processing and Applications. p.131-162. https://doi.org/10.1016/ B978-0-12-816695-6.00005-2

Espejo-Carpio, F. J., C. D. Gobba, A. Guadix, E. M. Guadix, \& J. Otte. 2013. Angiotensin i-converting enzyme inhibitory activity of enzymatic hydrolysates of goat milk protein fractions. Int. Dairy J. 32:175-183. https:/doi.org/10.1016/j. idairyj.2013.04.002

Hsueh, W. A. \& K. Wyne. 2011. Renin-angiotensin-aldosterone system in diabetes and hypertension. J. Clin. Hypertens. 13:224-237. https:/doi.org/10.1111/j.1751-7176.2011.00449.x

Iltchenco, S., A. P. Kempka, \& R. C. Prestes. 2017. Profiles of enzymatic hydrolysis of different collagens and derivatives over time. Revista Brasileira de Tecnologia Agroindustrial. 11:2165-2185. https://doi.org/10.3895/rbta.v11n1.2755

Jamhari, L. M. Yusiati, E. Suryanto, M. N. Cahyanto, Y. Erwanto, \& M. Muguruma. 2013. Comparative study on angiotensin converting enzyme inhibitory activity of hydrolysate of meat protein of Indonesian local livestocks. J. Indones. Trop. Anim. Agric. 38:27-33. https://doi. org/10.14710/jitaa.38.1.27-33

Kasim, A., D. Novia, S. Mutiar, \& J. Pinem. 2013. Karakterisasi kulit kambing pada persiapan penyamakan dengan gambir dan sifat kulit tersamak yang dihasilkan. Majalah Kulit, Karet dan Plastik 29:1-12. https://doi.org/10.20543/mkkp. v29i1.213

Khiari, Z., M. Ndagijimana, \& M. Betti. 2014. Low molecular weight bioactive peptides derived from the enzymatic hydrolysis of collagen after isoelectric solubilization/precipitation process of turkey by-products. Poult. Sci. 93:23472362. https://doi.org/10.3382/ps.2014-03953

León-López, A., L. F. Jiménez, A. D. H. Fuentes, R. G. C. Montiel, \& G. Aguirre-álvarez. 2019. Hydrolysed collagen from sheepskins as a source of functional peptides with antioxidant activity. Int. J. Mol. Sci. 20:3931. https://doi. org/10.3390/ijms20163931

Liu, M., M. Du, Y. Zhang, W. Xu, C. Wang, K. Wang, \& L. Zhang. 2013. Purification and identification of an ace inhibitory peptide from walnut protein. J. Agric. Food Chem. 60:4097-4100. https://doi.org/10.1021/jf4001378

Lodhi, G., Y. S. Kim, E. K. Kim, J. W. Hwang, H. S. Won, W. Kim, S. H. Moon, B. T. Jeon, \& P. J. Park. 2018. Isolation and characterisation of acid- and pepsin-soluble collagen from the skin of cervus korean temminck var. mantchuricus swinhoe. Animal Prod. Sci. 58:585-594. https://doi. org/10.1071/AN16143

Luderman, L. N., G. Unlu, \& E. W. Knapik. 2017. Zebrafish developmental models of skeletal diseases. Curr. Top. Dev. Biol. 124:81-124. https://doi.org/10.1016/bs.ctdb.2016.11.004

Martínez-Ortiz, M. A., A. D. H. Fuentes, D. J. P. González, R. G. C. Montiel, A. V. Torres, \& G. A. Álvarez. 2015. Extraction and characterization of collagen from rabbit skin: partial characterization. CYTA J. Food. 13:253-258. https://doi.org /10.1080/19476337.2014.946451

Muyonga, J. H., C. G. B. Cole, \& K. G. Duodu. 2004. Fourier transform infrared (ftir) spectroscopic study of acid soluble collagen and gelatin from skins and bones of young and adult Nile Perch (Lates niloticus). J. Food Chem. 86:325332. https://doi.org/10.1016/j.foodchem.2003.09.038

Naffa, R., G. E. Norris, \& G. Holmes. 2019. Insights into the molecular composition of the skin and hide used in leather manufacture. J. Am. Leather Chem. Assoc. 114:29-37.

Noorzai, S., C. J. R. Verbeek, M.C. Lay, \& J. Swan. 2020. Collagen extraction from various waste bovine hide sources. Waste Biomass Valorization. 11:5687-5698. https://doi. org/10.1007/s12649-019-00843-2

Permadi, E., J. Jamhari, E. Suryanto, Z. Bachruddin, \& Y. Erwanto. 2019. The potential of hydrolysate from rabbit meat protein as an angiotensin converting enzyme inhibitor. Buletin Peternak. 43:31-37. https://doi.org/10.21059/ buletinpeternak.v43i1.31495

Sujarwanto, R. O., Jamhari, E. Suryanto, Rusman, Setiyono, E. Triyannanto, Y. Erwanto \& R. Yuliatmo. 2018. Increased inhibition of angiotensin converting enzyme (ace) obtained from indonesian buffalo meat protein using sep-pak plus c18. Pak. J. Nutr. 17:434-440. https://doi.org/10.3923/ pjn.2018.434.440

Sadeghi, S., M. Darvish, M. Sedighi, S. O. R. Siadat, \& H. Jalili. 2019. Enzymatic hydrolysis of microalgae proteins using serine proteases: A study to characterize kinetic parameters. J. Food Chem. 284:334-339. https://doi.org/10.1016/j. foodchem.2019.01.111

Tabarestani, H. S., Y. Maghsoudlou, A. Motamedzadegan, A. R. S. Mahoonak, \& H. Rostamzad. 2012. Study on some properties of acid-soluble collagens isolated from fish skin and bones of rainbow trout (Onchorhynchus mykiss). Int. Food Res. J. 19:251-257.

Vidal, A. R., R. L. Cansian, R. O. Mello, E. H. Kubota, I. M. Demiate, A. A. F. Zielinski, \& R. C. P. Dornelles. 2019a. Effect of ultrasound on the functional and structural properties of hydrolysates of different bovine collagens. Food Sci. Technol. 40:346-353. https://doi.org/10.1590/fst.00319

Vidal, A. R., L. P. Duarte, M. M. Schmidt, R. L. Cansian, I. A. Fernandes, R. O. Mello, I. M. Demiate, \& R. C. P. Dornelles. 2019b. Extraction and characterization of collagen from sheep slaughter by-products. Waste Manag. 102:838-846. https://doi.org/10.1016/j.wasman.2019.12.004

Wahyuningsih, R., A. Pertiwiningrum, A. Rohman, N. A. Fitriyanto, \& Y. Erwanto. 2018. Optimization of conditions for extraction of pepsin-soluble collagen from Indonesian local " Kacang " goatskin by response surface 
methodology. Am. J. Anim. Vet. Sci. 13:70-75. https://doi. org/10.3844/ajavsp.2018.70.75

Widodo, H. S., T. W. Murti, A. Agus, \& W. Widodo. 2019. Mengidentifikasi peptida bioaktif angiotensin converting enzyme-inhibitor (acei) dari kasein $\beta$ susu kambing dengan polimorfismenya melalui teknik in silico. Jurnal Aplikasi Teknologi Pangan. 7:180-185. https://doi. org/10.17728/jatp.3008

Winarti, A., F. Rahmawati, N.A. Fitriyanto, J. Jamhari, \& Y. Erwanto. 2019. Hydrolyzation of duck meat protein using Bacillus cereus $\mathrm{td} 5 \mathrm{~b}$ protease, pepsin, trypsin and their potency as an angiotensin converting enzyme inhibitor.
J. Indones. Trop. Anim. Agric. 44:266-276. https://doi. org/10.14710/jitaa.44.3.266-276

Wolf, P. 1983. A Critical reappraisal of waddell's technique for ultraviolet spectrophotometric protein estimation. Anal. Biochem. 129:145-155. https://doi. org/10.1016/0003-2697(83)90062-3

Yuliatmo, R., N. A. Fitriyanto, Z. Bachruddin, Supadmo, Jamhari, \& Y. Erwanto. 2017. Increasing of angiotensin converting enzyme inhibitory derived from chicken leg. Int. Food Res. J. 24:1799-1804 